Ritrýnd grein birt 31. desember 2018

\title{
Margbrotið hlutverk leiklistarkennarans í kennslu leiklistar í tengslum við innleiðingu á leiklist
}

\author{
Rannveig Björk Porkelsdóttir
}

\begin{abstract}
Um höfundinn $\longrightarrow$ About the author $>$ Heimildir
Viðfangsefni pessarar greinar er að varpa ljósi á og dýpka skilning á leiklistarkennslu í grunnskóla við innleiðingu leiklistar sem fags. Greinin byggist á doktorsritgerð höfundar frá árinu 2016. Bakgrunnur doktorsverkefnisins er sá að árið 2013 kom út ný aðalnámskrá grunnskóla fyrir tiltekin greinasvið og var leiklist pá skilgreind sem sérstakt listfag $́$ í fyrsta skipti. Viðfangsefni og rannsóknarspurning verkefnisins var eftirfarandi: Hvernig er staðið að innleiðingu leiklistar í grunnskólum á Íslandi? Rannsóknin var byggð á eigindlegri rannsóknarhefð og fellur undir etnógrafíska rannsókn á grunni félags- og menningarkenninga. Markmið etnógrafíunnar er að leitast við að skoða og skilja sjónarhorn peirra sem rannsakaðir eru. Veturinn 20132014 heimsótti ég tvo skóla í Reykjavík, Brekkuskóla (5. bekkur) og Fjallaskóla (6. bekkur), og fylgdist par með tveimur kennurum kenna leiklist. Niðurstöðurnar eru kynntar með menningarlegu portretti, pykkum lýsingum og í gegnum narratívu. Kenningar Stephen Kemmis og Peter Grootenboer „practice architectures“ eru hafðar að leiðarljósi í rannsóknarvinnunni. Ég grandskoðaði menningu skólanna með tilliti til kenninga Stephen Kemmis um arkitektúr og vistfræði starfshátta. Niðurstöður rannsóknarinnar kalla á breytingar í faglegri próun leiklistarkennarans. Enn fremur kallar rannsóknin á endurskilgreiningu leiða til að styðja starfspróun leiklistarkennarans og breyta kennsluháttum hans, nemendum til góða.
\end{abstract}

Efnisorđ: Leiklist, listkennsla, listmenntun, innleiðing, aðalnámskrá, starfshættir.

\section{Inngangur}

Rýni og rannsóknir á menntun á 21. öld krefjast nýrrar nálgunar sem snýr einkum að sköpunargáfu, aðlögunarhæfni og betri samskiptahæfni einstaklingsins. Dessi nýja nálgun í menntamálum byggist á hugmyndum manna um víðtækari pjálfun ungs fólks til að gera pað hæfara og auka sjálfstraust pess í breyttum heimi. Börnum sem hreyfa sig lítið fjölgar mjög og leikir sem krefjast hreyfingar virðast vera á undanhaldi. Í stað eigin leikja meðtaka börn leiki annarra með pví að horfa á sjónvarp eða leika sér í skipulögðum tölvuleikjum sem eru ímyndun annarra (Landlæknisembættið, 2004; Ása Ragnarsdóttir og Rannveig Porkelsdóttir, 2010). Баð er mikilvægt að hvetja börn til að reyna á ímyndunarafl sitt með pví að skapa sína eigin leiki par sem pau glíma við vandamál, skapa og taka sjálfstæðar ákvarðanir. Skilningur eykst og nám á sér stað pegar nemandinn setur sig í hlutverk, kannar og skoðar mikilvæga pætti í mannlegum samskiptum og tekur sjálfstæðar ákvarðanir í ferlinu. Í gegnum leiklist lærir nemandinn að setja sig í spor annarra og hún stuðlar markvisst að pví að styrkja sjálfsmynd nemenda pannig að peir taki ákvarðanir sem byggðar eru á eigin skoðunum og tilfinningum frekar en áhrifum frá félögum. 
Börn hafa sérstaka pörf fyrir að tjá sig í hlutverkaleik og pau hafa einstakt lag á að breyta umhverfi sínu í págu pess hlutverkaleiks sem pau eru í hverju sinni. Rannsóknir sýna fram á eflingu málbroska í gegnum leiklist og nemendum sem eiga við námsörðugleika að stríða gengur betur að læra tungumál og efla félagsfærni í gegnum leiklist (Ása Ragnarsdóttir og Rannveig Dorkelsdóttir, 2010). Einnig eykst skilningur nemenda á efni sem unnið er með pegar aðferðir leiklistarinnar eru notaðar með pví að leika pað (Ragnarsdóttir og Thorkelsdóttir, 2013).

Markmið rannsóknarinnar, sem greinin fjallar um, er að stuðla að aukinni pekkingu í listkennslu og innleiðingu leiklistar sem nýrrar faggreinar í grunnskólum á Íslandi. Bakgrunnur rannsóknarinnar er sá að árið 2013 kom út ný aðalnámskrá grunnskóla með skiptingu í greinasvið og par var leiklist skilgreind sem sérstakt listfag í fyrsta skipti. Viðfangsefni og rannsóknarspurning verkefnisins var eftirfarandi: Hvernig er staðið að innleiðingu leiklistar í grunnskólum á Íslandi?

Unnið var með fjórar undirrannsóknarspurningar:

- Hvað einkennir kennsluhætti leiklistar í tveimur grunnskólum?

- Hvernig er hægt að skilja og lýsa starfspróun leiklistarkennarans yfir eitt skólaár?

- Hver er upplifun og reynsla nemendanna af leiklistarkennslunni og pátttöku í sýningu?

- Hvernig skilgreina skólastjórarnir í báđum skólunum menningu leiklistar?

\section{Að skoða listmenntun af skilningi}

Árin 2008 og 2009 var Anne Bamford beðin, af páverandi mennta- og menningarmálaráðherra, að meta gæði menntunar á sviði lista og menningar á Íslandi. Matið snerist fyrst og fremst um аð leita svara við eftirfarandi spurningum: Нvað er verið að gera í listmenntun og hvernig er pað gert? Hver eru gæði listmenntunar á Íslandi? Hvaða tækifærum og áskorunum stöndum við frammi fyrir á pessu sviði?

Helsta niðurstaða hennar var að listmenntun á Íslandi væri á háu stigi í alpjóðlegum samanburði og helgaðist menntunin fyrst og fremst af pví að byggja upp færni og pekkingu á sviði listforma, einkum sjónlista, tónlistar, hönnunar og smíða. Einnig, en í minni mæli, í dansi, leiklist, ljósmyndun og kvikmyndagerð. Bamford komst einnig að peirri niðurstöðu að gera ætti greinarmun á pví sem annars vegar má kalla beina listmenntun (t.d. kennslu í skapandi listum, tónlist, leiklist og listiðn) og hins vegar menntun með listrænu ívafi (t.d. beitingu listanna sem uppeldistækis í öðrum fögum, eins og tölvísi, læsi og tæknigreinum). Bamford segir að í skólum purfi að leggja aukna áherslu á sköpun með nýstárlegum skapandi námsaðferðum, par á meðal í listgreinum, og náin tengsl ættu að vera á milli ferlis og afurðar (Bamford, 2011).

Talsmenn listmenntunar sjá hana sem einstakt pekkingarsvið byggt á eigin gildum og fræðisetningum. Dessu lýsir Shifra Schonman (2016, bls. 22) og segir pá líta á listir sem sameiginlegt tungumál mannkynsins. Schonman spyr: Hvernig geta listir menntað fólk? Hún ræðir pá hugmynd að gera leikræna tjáningu/listir að miðpunkti námskrárinnar og setur fram nýstárlega hugsun með pví að segja: „Ef listin er meginviðfangsefni lífsins er óparft að segja að hún eigi að vera miðpunktur námskrárinnar pví hún er pegar komin pangað“" (bls. 27). Ef við höldum okkur við rökfærslu Schonman, er „/.../ engan veginn víst að allur stuðningur við listir innan menntakerfisins komi að lokum nemendum og menntun peirra til góða“" (bls.15). Meginrök Schonman eru að listir geti aukið skemmtanagildi viðfangsefna en óvíst sé að pær mennti endilega unga fólkið.

Susanne Keuchel (2016, bls. 39) hefur sett fram yfirlit um menntun á lista- og menningarsviði sem gæti hugsanlega gefið vísbendingu um hvernig listir geti menntað fólk. 
Félagslegt sviơ: menningarhefơ, fjölbreytni, sjálfsmynd og próun
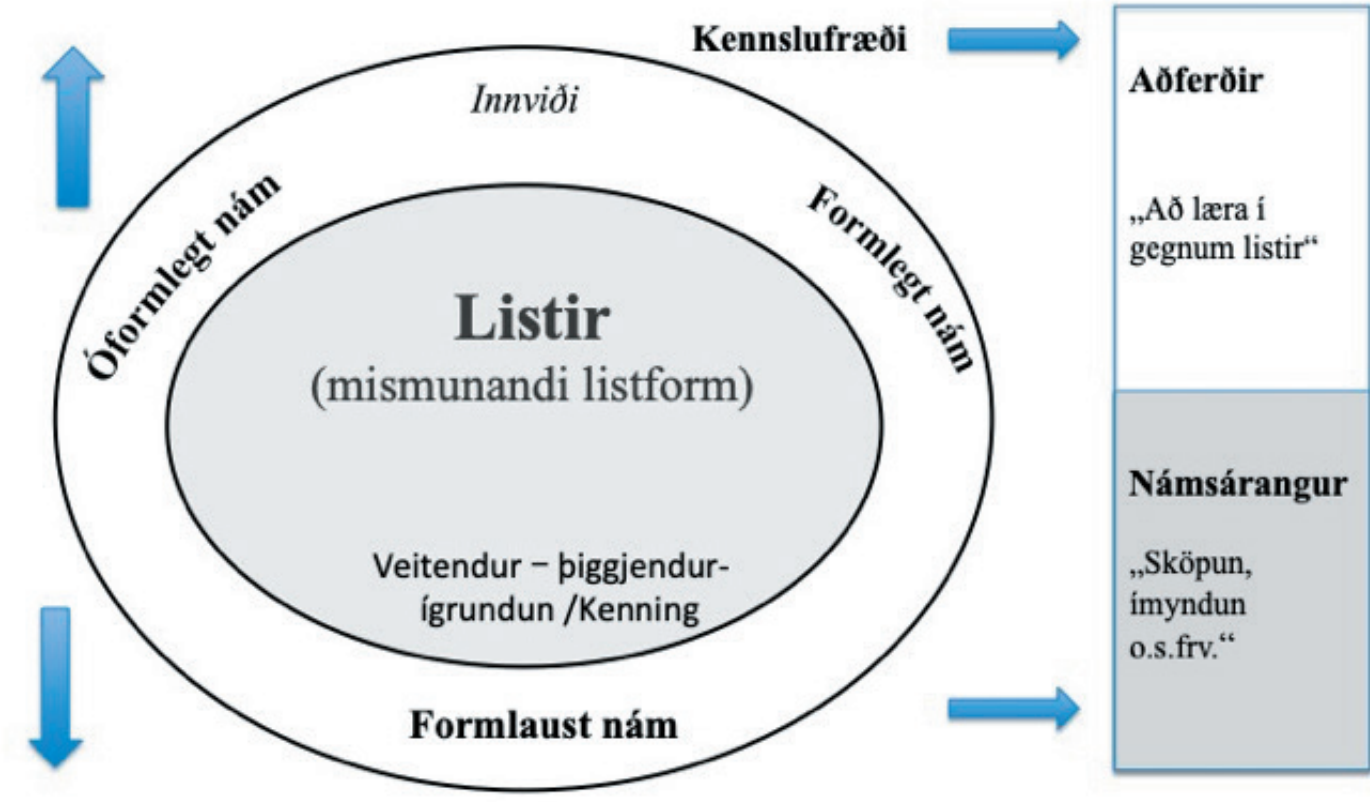

Viðfangið: túlkun lífsreynslu, félagsleg tjáskipti og uppbygging sjálfsins

Mynd 1. Skilningsstig og skilgreining listmenntunar. ${ }^{1}$.

Mynd 1 byggist á stuttum lýsingum sérfræðinga í sextán löndum frá fimm heimsálfum sem benda til pess að mismunandi viðhorfsbreytur komi til sögunnar pegar skilgreina skal listmenntun. Dessar breytur tengjast viðfangi, pjóðfélagsgerð og uppeldisstigi. Keuchel telur að viðfangið feli í sér túlkun lífsreynslu, félagsleg tjáskipti og uppbyggingu sjálfsins. Félagslega sviðið tekur til menningarhefðar, fjölbreytni, sjálfsmyndar og próunar. Að mati Keuchel tekur uppeldisfræðilegi pátturinn til náms með tilstuðlan listanna (aðferðir) og framsetningar pess sem lært hefur verið. Hún er einnig peirrar skoðunar að til að skilja menntun með list sem aðalinntak purfi mismunandi stig samverkandi listrænna áhrifa (listrænnar skynjunar):

Allt snýst petta um að læra list, að læra í gegnum listina, eða læra um listina. Skoða ætti list sem miðpunkt pekkingaröflunar. Dví ættu kennarar að einbeita sér að pví að læra um listir og auka fagpekkingu sína innan listrænna fræðasviða. Einnig má vel vera að samverkandi listræn áhrif ljúki upp dyrum nýrra fræðigreina með eins konar yfirfærslu. (bls. 38)

Dessar aðferðir tengjast hugtakinu listmenntun með mismunandi áherslum í ólíkum löndum og menningarheimum. Баð líkan, eða sú fyrirmynd, sem lýst er hér að framan getur hjálpað til við að koma reiðu á:

/.../ mismunandi viðhorf til skilgreiningar og skilnings á listmenntun án pess að reynt sé að kortleggja alla pætti slíkrar menntunar. Líkanið sýnir að grundvallargildi samfélagsins tengjast innihaldi listmenntunar og skilningi á henni. (bls. 39)

Líkan Keuchel beinir kastljósinu að mikilvægi menntunar í listum, gegnum listir og um listir. Listmenntun er óaðskiljanlegur páttur í félagslegri og menningarlegri skynjun hvers lands.

Með leyfi frá Keuchel (2016, bls.. 39) 
John O’Toole, og fleiri helstu höfundar áströlsku námskrárinnar á sviði lista, voru sammála um eftirfarandi undirstöðupæetti listmenntunar:

Dekking og menntun í listum og gegnum listir felur í sér líkamlega skynjum ásamt huglægu og tilfinningalegu ferli og veitir pannig fagurfræðilega innsýn, ólíkt öðrum fræðasviðum. Öll börn hafa listræna hæfileika og geta verið bæði veitendur og piggjendur listar; sköpun, ímyndun og leikur eru lykilpættir listanna. (O’Toole, 2015, bls. 190)

O’Toole kveður listir einnig vera sprottnar úr menningu og aðlagaðar og túlkaðar fyrir áhrif hennar. Hann segir að listir innan skólanna einkennist af miklu samstarfi og geri mismunandi kröfur um tíma og skipulag.

Með tilvísun til Schonman (2016), segir hún „/.../ við verðum að opna hugi okkar fyrir nýjum tímum nýrra kennslu- og námsaðferða. Við verðum að skilja pað kall tímans að við einbeitum okkur að pverfaglegum leiðum til að byggja á nýjan leik upp pekkingu sem felur í sér margbreytilega reynslu“ (bls. 27). Schonman lítur svo á að petta sé köllun listanna innan menntakerfisins. Gildi listmenntunar fyrir mannlega reynslu sé næg ástæða til að réttlæta sess hennar í námskrám skólanna (Winner og félagar, 2013, bls. 249).

Listir í sinni bestu mynd, segir Peter Abbs (2003) í bók sinni Against the flow: Education, the arts and postmodern culture, dýpka og skerpa skilning okkar á pví hvað pað er að lifa. Abbs telur að listir skipti máli „,vegna pess að - pegar best lætur - pjóna pær dýpri mannlegri hvöt til að skilja, samsamast og hefjast yfir; listir pjóna rótgróinni löngun til að lifa fyllra og fjölbreyttara lífi““.

Mér hafa alltaf fundist listir, og sér í lagi sköpun listaverka, gera einstaklingum kleift að hefja hverfult líf sitt upp á æðra svið táknrænna ævintýra og heimspekilegra spurninga. (bls. 67)

„Listir auðga skilning okkar á heiminum, bjóða birginn ríkjandi hugmyndafræði, víkka sjóndeildarhring okkar, vekja áhuga okkar og ánægju og beina athyglinni að mannlegum eiginleikum okkar,“ segir Mike Fleming (2012, bls. 1) í bók sinni The Arts in education, an introduction to aesthetics, theory and pedagogy par sem hann fjallar um nám í og gegnum listir. Hann segir:

Nám gegnum listir horfir fram hjá listforminu sjálfu og beinist að utanaðkomandi niðurstöðum sem oft birtast pegar listir eru nýttar með pverfaglegum hætti í námskránni til að örva nám í öđrum greinum. Nám í listum tengist oft námi innan viðkomandi fags /.../ en pað er einmitt pegar hugtök verða óljósari og byrja að blandast saman að áhugavert innsæi birtist. (bls. 68)

Fleming segir einnig að kennsla í listum verði að vera fólgin í fleiru en aðeins pví að kenna börnum að tjá sig með listsköpun. Hann heldur pví fram að ef kenna á börnum að meta list verði að einbeita sér bæði að listaverkinu sjálfu og upplifun barnanna í tengslum við pað.

Hvað innihaldi viðkemur er eðlilegt að ætlast til pess að nemendum sé kennt að taka pátt í eigin menningarsamfélagi og kynnast fjölbreyttri list pess og listformum. (bls. 45)

Listir geta með sanni gert tilkall til pess að vera hluti menntunar. Fyrir tilstuðlan listanna geta nemendur skapað nýja fagurfræðilega pekkingu og dýpkað mannlegar langanir sínar og reynslu.

\section{Menntun í leiklist}

Menntun í leiklist snýst um að pjálfa nemendur í aðferðum listgreinarinnar (t.d. spuna, persónusköpun og látbragðsleik) en ekki síður um læsi á leiklist í víðu samhengi og að dýpka skilning nemenda á sjálfum sér, mannlegu eðli og samfélagi (O’Toole, 2015). Leiklist er list 
augnabliksins. Með leiklist er hægt að takast á við pau mál sem efst eru á baugi í samfélaginu hverju sinni og brenna á nemendum. Samkvæmt aðalnámskrá grunnskóla eiga nemendur í gegnum leiklist að fá:

tækifæri til pess að setja sig í spor annarra og prófa sig áfram með mismunandi tjáningarform, hegðun og lausnir í öruggu umhverfi í skólanum. Hún styður nemandann 1 a a tjá, móta og miðla hugmyndum sínum og tilfinningum. Leiklist reynir auk pess stöðugt á samvinnu, samskipti, sköpun, tungumál, tjáningu, gagnrýna hugsun, líkams- og raddbeitingu. Allt fer petta fram í gegnum leik og sköpun. Nemendur beita töluðu máli bæði í spuna og í meðferð skrifaðs leiktexta. (Mennta- og menningarmálaráðuneytið, 2013, bls. 145)

Rannveig Björk Dorkelsdóttir (2012) segir í bók sinni Leikið með listina að í gegnum hlutverkaleik læri nemendur að pað sé hægt að túlka meiningu orða á annan hátt en bókstaflega:

Deir læa að takast á við ímyndaðar aðstæður, pjálfast í skipulagðri og markvissri samvinnu sem eflir félagsproska. Peir pjálfast í notkun talaðs máls, verða sjálfstæðari í vinnubrögðum og læra að koma fram. Pegar börn taka pátt í leiklist leitast pau við að skilja og viðurkenna samhengi milli menningar og gilda. Pau læra að leita að dulinni meiningu og uppgötva mismunandi pætti lífsins. (Rannveig Björk Porkelsdóttir, 2012)

Leiklistin styður nemendur í að tjá, móta og miðla hugmyndum sínum og tilfinningum par sem áhersla er lögð á næmi skynjunar, meðal annars á pví fagurfræðilega, úrvinnslu tilfinninga, eflingu ímyndunarafls og hæfni til tjáningar og samskipta. Dannig skerpist samfélagsvitund peirra og peir eru virkjaðir til lýðræðislegrar pátttöku (Thorkelsdóttir, 2016).

Leiklist reynir auk pess stöðugt á samvinnu, samskipti, sköpun, tungumál, tjáningu, gagnrýna hugsun og líkams- og raddbeitingu. Leiklist er einnig í eðli sínu sampætt listform par sem allar listgreinar koma saman (Mennta- og menningarmálaráduneytið, 2013). Leiklist getur haft félagsleg, fagurfræðileg og tilfinningaleg áhrif á fólk. Að horfa á leikrit getur hjálpað okkur að skilja sögu, menningu og samfélag í heild um leið og pað hjálpar nemendum að proskast sem persónur að taka pátt 1 a a skapa og flytja eigin texta og texta annarra; að geta gagnrýnt og rökrætt leikið efni á sviði á uppbyggjandi hátt og sett pað í menningarlegt og sögulegt samhengi (Thorkelsdóttir, 2016). O’Toole og Johanna O'Mara (2007) tala um prjár víddir í tilgangi náms í leiklist, út frá sköpun (e. making) p.e. að semja handrit, leikstýra eða hanna; koma fram (e. presenting), p.e. að setja eitthvað fram, eins og leikarar á sviði, og svörun (e. responding). Hið síðast talda vísar til sambands leikara og áhorfenda meðan á leiksýningu stendur og hvernig pessir aðilar bregðast hvorir við öðrum. Dau leggja einnig áherslu á samstillta hugmyndafræði pegar leiklist er kennd, pað er að nemandinn öðlist vitsmunalegan skilning á listfaginu sjálfu og peim aðferðum sem notaðar eru í leiklist, proskist og próist í gegnum leiklistina, öðlist félagshæfni með kennslufræðilegri nálgun í leiklist, p.e. læri í gegnum leiklist og læri leiklist með hagnýtum hætti (O'Toole og O'Mara, 2007, bls. 207).

\section{Hlutverk leiklistarkennarans}

Samkvæmt líkani Michael Anderson (2006), sem er prófessor við háskólann í Sydney í Ástralíu, um starfspróun leiklistarkennara pá er eitt af hlutverkum leiklistarkennarans að stuðla að viðhorfsbreytingu: 


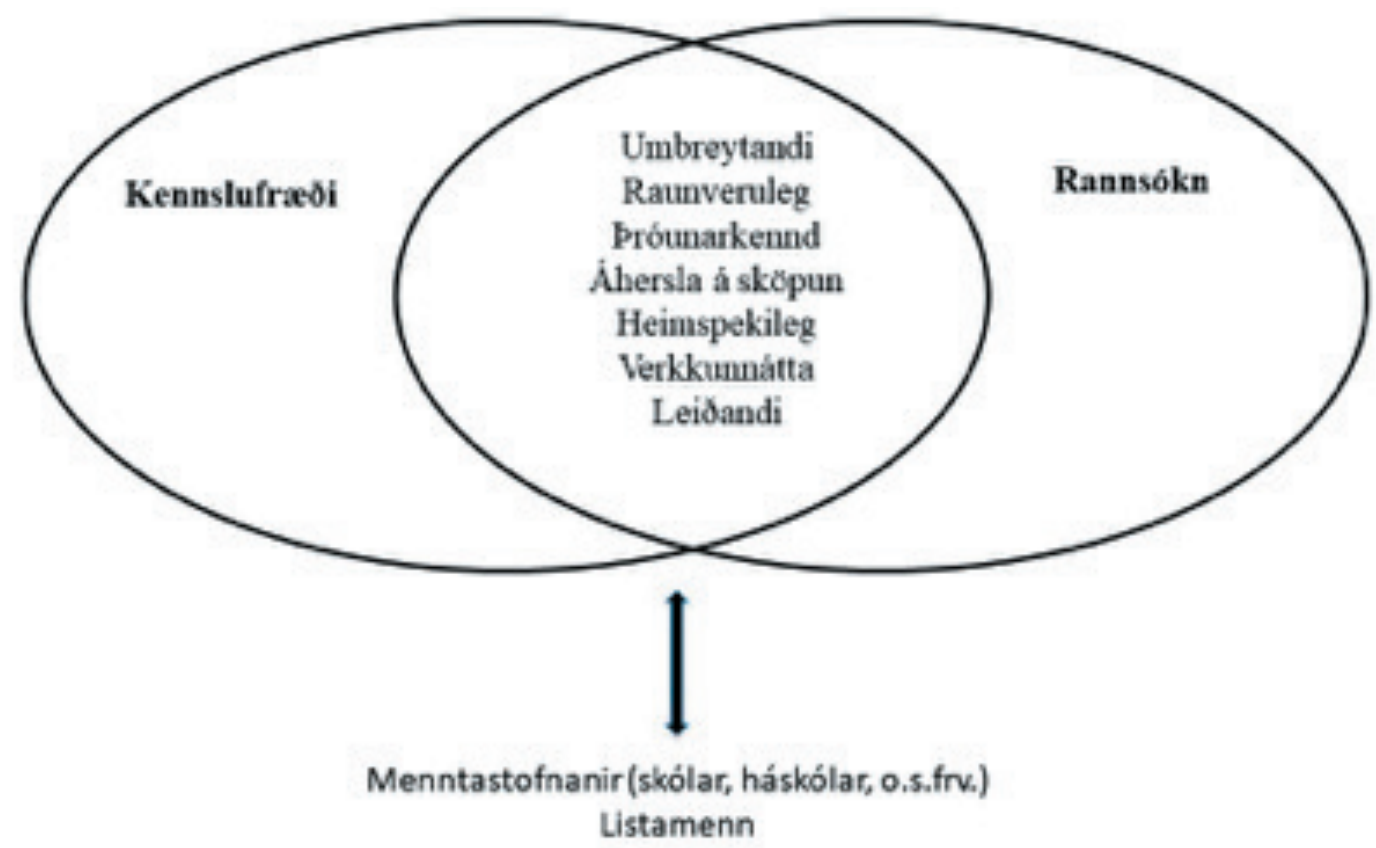

Mynd 2. Líkan af starfspróun leiklistarkennarans. ${ }^{2}$

Anderson (2012) bendir á að leiklist gegni einstöku hlutverki á skurðpunktinum milli fræðilegrar, skapandi og líkamlegrar menntunar og að leiklistarkennsla sé fagurfræðileg menntun sem sé yfirfæranleg, p.e. leiklist geti örvað fræðilegan, félagslegan og tilfinningalegan proska ungs fólks. Leiklistarmenntun og almenn listmenntun sé uppeldisfræði sem byggist á arfleifð en geti engu að síður nútímavætt skólanám. Hann segir einnig að kjarni kennarastarfsins sé að stórum hluta sá að eiga nóg til í verkfærakistunni fyrir nemendur til að vinna með. Kennarinn parf pví stöðugt að vera að próa aðferðir sínar og verkefni og taka við nýjum hugmyndum frá nemendum. Anderson talar einnig um að leiklistarkennarar purfi að umbreyta kennslufræðinni; kraftur listarinnar sé slíkur að pað ætti án vafa að hvetja leiklistarkennara til að nota listina og um leið nemendur til að hafa áhrif á samfélagið par sem leiklistin sé sannarlega list augnabliksins. Leiklistarkennari purfi pví að stuðla að próun og vera opinn fyrir pví að taka við hugmyndum frá nemendum og framkvæma pær. Kennarinn purfi líka að geta próað hugmyndir nemenda og hafa opinn huga gagnvart pví. Oft er eitthvert mál í samfélaginu sem brennur t.d. á unglingum og gæti verið gott að vinna með í leiklistartímum til að stuðla að gagnrýninni hugsun (Anderson, 2006).

\section{Framkvæmd rannsóknarinnar}

Í doktorsnámi mínu við norska vísinda- og tækniháskólann í Prándheimi, NTNU, rannsakaði ég hvernig staðið er að innleiðingu leiklistar í grunnskólum á Íslandi. Markmið rannsóknarinnar var að stuðla að aukinni pekkingu á listkennslu og innleiðingu leiklistar sem nýrrar faggreinar í grunnskólum á Íslandi. Bakgrunnur rannsóknarinnar er sá að árið 2013 kom út ný aðalnámskrá grunnskóla, greinasvið, og par var leiklist skilgreind sem sérstakt listfag í fyrsta skipti. Í kjölfarið myndaðist nokkur spenna í sambandi við pað hvort skólarnir gæetu kennt petta nýja fag, hvort hæfir kennarar fengjust til starfa og hvort leiklistin næði góðri fótfestu. Viðfangsefni og rannsóknarspurning verkefnisins var eftirfarandi: Hvernig er staðið аð innleiðingu leiklistar í grunnskólum á Íslandi? 
Unnið var með fjórar undirrannsóknarspurningar:

- Hvað einkennir kennsluhætti leiklistar í tveimur grunnskólum?

- Hvernig er hægt að skilja og lýsa starfspróun leiklistarkennarans yfir eitt skólaár?

- Hver er upplifun og reynsla nemendanna af leiklistarkennslunni og pví að taka pátt í sýningu?

- Hvernig skilgreina skólastjórarnir í báđum skólunum menningu leiklistar?

Rannsóknin byggðist á eigindlegri rannsóknarhefð og fellur undir etnógrafíska rannsókn á grunni félags- og menningarkenningar. Markmið etnógrafíunnar er að leitast við að skoða og skilja sjónarhorn peirra sem rannsakaðir eru. Veturinn 2013-2014 heimsótti ég tvo skóla í Reykjavík, Brekkuskóla (5. bekkur) og Fjallaskóla (6. bekkur), og fylgdist par með tveimur kennurum kenna leiklist. Annar kennarinn var á sínu fyrsta ári í kennslu með 32 nemendur í einum bekk en í leiklist var peim skipt upp í tvo hópa eftir kyni; 17 stelpur og 15 strákar (Brekkuskóli). Hinn kennarinn var með mikla kennslureynslu og kenndi 25 nemendum af báðum kynjum; 10 stelpum og 15 strákum (Fjallaskóli). Eins og fram hefur komið var um etnógrafíska rannsókn að ræða og var gagna aflað með pátttökuathugun og opnum viðtölum við kennara, nemendur og skólastjóra. Eins héldu kennararnir dagbækur og var aðalnámskrá grunnskóla, sem og skólanámskrá beggja skóla greind. Túlkunarfræðilegri nálgun (Meyers, 1997) var beitt við greiningu gagnanna, sem og margprófun (e. triangulation). niðurstöðurnar voru kynntar með menningarlegu portretti, pykkum lýsingum og í gegnum narratívu. Menning skólanna var grandskoðuð með tilliti til kenninga Stephen Kemmis um uppbyggingu og vistfræði starfshátta. Kemmis og félagar (2014) útskýra starfshætti sem skipulegar samstæður yrðinga, gjörða og tengsla sem fléttast saman í verknaði par sem vinnuferlið sjálft er megintilgangur starfsháttarins sem skapar peim samstöðu. Kenningu um uppbyggingu starfshátta er betur lýst hér á eftir.

\section{Kenningar um uppbyggingu starfshátta}

Kenning peirra Kemmis og Peter Grootenboer (2008) um uppbyggingu starfshátta snýst um breyttar aðferðir við menntun, p.m.t. leiklistarmenntun, og byggistá starfsháttakenningu Theodor Schatzki (1996, 2002). Leiðir til uppbyggingar starfshátta vísa til sértækrar menningarorðræðu, svo og efnislegra-hagfræðilegra og félagslegra-pólitískra aðstæðna sem fyrir eru á tilteknum vettvangi eða hafa verið fluttar pangað. Pessar aðstæður ýmist auðvelda eða torvelda starfshætti. Kemmis og félagar útskýra starfshætti sem skipulegar samstæður yrðinga (e. sayings), gjörða (e. doings) og tengsla (e. relating). Starfshættir eru ein tegund félagslega uppbyggðra mannlegra athafna par sem fólk tekur að tala sameiginleg tungumál og próa sameiginlegan skilning (yrðingar; til samans er pessu oft lýst sem hugrænni, vitsmunalegri pekkingu). Fólk vinnur einnig saman að athöfnum og starfsemi (gerðum/gjörð; sem pað lýsir með orðunum leikni og hæfni) og sameiginlegum leiðum til að tengjast og kunna skil hvert á öðru (tengsl). Vinnuferli (e. project of practice) er einfaldlega svar fólks við spurningunni „Hvað ertu að gera?“ meðan á verki stendur.

Kenningin um uppbyggingu starfshátta tekur til lífsviðhorfa og reynslu peirra sem starfa að menntun. Kenningin styðst við nokkur hugtök og eru pau: starfshefðir, landslag starfshátta og verufræði vettvangs. Hefðbundnir starfshættir eru fólgnir í peim venjum og skilningi sem próast á vettvangi pegar til lengri tíma er litið. Landslag starfsháttanna er sá hluti hins ytri heims par sem starfsemin fer fram. Verufræði vettvangs er sérstök lífsviðhorf og lífsvenjur sem fólk hefur tamið sér á vettvangi (Østern o.fl., 2016; Kemmis o.fl., 2014).

Hugmyndafræðin að baki uppbyggingu starfshátta gerir ráð fyrir að pegar kennari gengur inn í starfssamfélag, eins og til dæmis skóla, sé vettvangurinn fyrir hendi. Dessi vettvangur hefur pegar byggt upp sinn eigin stíl starfshátta í tengslum við yrðingar (p.e. merkingarfræðilegt rými), gerðir (p.e. efnislegan tíma og rúm) og tengsl (félagslegt rými). Kemmis og félagar (2014) halda pví fram að breytingar á sviði menntunar snúist ekki einvörðungu um pað hvernig kennarar kenna eða 
nemendur læra; hér er einnig alltaf um pað аð ræða að breyta uppbyggingu starfshátta á tilteknum vettvangi og hinni verklegu vistfræði sem tengir saman mismunandi athafnir og samskipti aðila sem háðir eru hverjir öđrum innbyrðis. Dví er pað svo að pegar gerðar eru breytingar á sviði menntunar, t.d. með pví að bæta nýrri námsgrein eins og leiklist inn í námskrána, pá dugar ekki аð hliðra einfaldlega til kennsluaðferðum eða námstilhögun nemenda; pað verður líka að horfa til allra pátta starfseminnar (Thorkelsdóttir, 2016).

\section{Niðurstöður rannsóknarinnar}

\section{Fjögur mismunandi sjónarhorn á innleiðingu leiklistar}

Hér verður greint frá niðurstöðum rannsóknarinnar. Við framsetningu menningarlegs portretts af innleiðingu leiklistar og túlkun niðurstaðna voru notuð fjögur sjónarhorn og voru pau tengd við rannsóknarspurningarnar fjórar. Dví verða niðurstöðurnar kynntar út frá fjórum sjónarhornum, sem eru: (1) Sjónarhorn rannsakandans: byggt á pátttökuathugun hans á kennsluháttum leiklistarkennarans við að kenna leiklist. (2) Sjónarhorn leiklistarkennarans: narratíva leiklistarkennarans og starfskenning. (3) Sjónarhorn nemendanna: reynsla og upplifun nemendanna af leiklist. (4) Sjónarhorn skólastjóranna á leiklistarkennslu í skólum sínum. Sett voru fram sérstök greinandi pemu sem voru lýsandi fyrir pað sem fram fór í leiklistarstofunni og fyrir starf leiklistarkennarans og verða pemun notuð sem fyrirsagnir í niðurstöðunum eins og sjá má í töflu 1.

Tafla 1. Margbrotið hlutverk leiklistarkennarans í kennslu leiklistar samhliða innleiðingu á leiklist.

\begin{tabular}{|c|c|c|c|}
\hline \multicolumn{4}{|c|}{ Birtingarmynd leiklistarkennslu... } \\
\hline $\begin{array}{l}\text { frá sjónarhorni } \\
\text { rannsakandans }\end{array}$ & $\begin{array}{l}\text { frá sjónarhorni } \\
\text { kennarans }\end{array}$ & frá sjónarhorni nemendanna & $\begin{array}{l}\text { frá sjónarhorni } \\
\text { skólastjórans }\end{array}$ \\
\hline Mikilvagi reynslunnar & $\begin{array}{l}\text { Viðurkenning sem } \\
\text { fagmaður i faginu }\end{array}$ & $\begin{array}{l}\text { Til að hafa gaman, leika og } \\
\text { lecra }\end{array}$ & Mikilvagi leiksýninga \\
\hline Leikmenning & & & Mikilveegi pess að námið \\
\hline Lardómsmenning & $\begin{array}{l}\text { Sjálfsmynd } \\
\text { leiklistarkennarans }\end{array}$ & $\begin{array}{l}\text { Geta túlkað leikpersónu } \\
\text { á sviði í gódu samspili við }\end{array}$ & $\begin{array}{l}\text { sé skemmtilegt } \\
\text { Leiklist sem vörumerki }\end{array}$ \\
\hline Mikilvagi & Að tilheyra & medleikara & Letkilst sem Dornmerke \\
\hline samstarfsins & skólasamfélaginu & $\begin{array}{l}\text { Nýti sér leikmuni, búninga } \\
\text { og einfaldan svidsbúnad }\end{array}$ & \\
\hline $\begin{array}{l}\text { Flókið hlutverk } \\
\text { leiklistarkennarans }\end{array}$ & $\begin{array}{l}\text { Baráttan við } \\
\text { kennslufreæi leiklistar }\end{array}$ & $\begin{array}{l}\text { Lara að vinna með ӧдrum } \\
\text { án pess endilega að vilja paðd }\end{array}$ & \\
\hline & & Lara aঠ hlusta og taka tillit & \\
\hline
\end{tabular}

\section{Frá sjónarhorni rannsakandans:}

Niðurstöður rannsóknarinnar út frá sjónarhorni rannsakandans svara fyrstu rannsóknarspurningunni, sem var: Hvað einkennir kennsluhetti leiklistar í tveimur grunnskólum? Раð sem stendur upp úr er mikilvægi reynslunnar, mikilvægi samstarfsins og leikja- og lærdómsmenning. 


\section{Mikilvagi reynslunnar}

Dað sem var áberandi í báðum skólunum var mikilvægi reynslunnar. Annar kennarinn var nýútskrifaður og átti í töluverðum erfileikum með skipulagningu kennslunnar. Hann átti í verulegum erfiðleikum með að fóta sig í nýrri grein, vissi oft ekki hvað hann mátti og átti að gera í kennslu og var oftar en ekki í innri baráttu við sjálfan sig af pví að hann náði illa tökum á pví sem hann var að gera. Dessi barátta við kennslufræðina skapaði óöryggi hjá kennaranum og varð til pess að kennslan varð oft á tíðum tilviljunarkennd; hún varð háð tilfinningu og svo virtist sem hann ætti erfitt með að skipuleggja kennsluna og próa hana áfram. Hinn kennarinn var reyndari en kaus að búa ekki til kennsluáætlun. Hann sagði: „Kennsluáætlunin er ekki gerð fyrir tímann par sem ég vil bæði byggja á reynslu og tilfinningu ..." Hann var með mjög skýrar reglur um pað hvað mátti og hvað mátti ekki í leiklistartímunum og lagði áherslu á að: „Allir verða að fara eftir fyrirmælunum og gera pað sem kennari segir. Líka í öðrum tímum. Рað hvernig pú kemur fram hefur áhrif á pað hvernig aðrir sjá pig." Kennararnir voru sammála um að leiklistarkennsla væri erfið og pað að koma inn í slíka kennslu án stuðnings gæti leitt til pess að kennarinn hreinlega gæfist upp og hætti í starfi.

\section{Leikmenning}

Dað sem einkenndi kennsluhætti í báðum skólunum var áhersla á leikmenningu. Báđir kennararnir áttu í töluverðum erfiðleikum með að skipuleggja kennsluna og gripu oftar en ekki til leikja til að hafa stjórn á bekkjunum. Strákarnir í Brekkuskóla áttu í erfiðleikum með að sampykkja að pað væri hægt að læra í gegnum leik og vildu oftar en ekki bara leika sér. Deir sáu ekki tilganginn í pví sem á eftir fór. Dví var pað svo að margir leikir voru í hverri kennslustund, sumir með kennslufræðilegan tilgang en aðrir ekki.

\section{Lærdómsmenning}

Í báðum skólunum var leiklistarkennsla miðuð að pví að setja upp leikrit. Báđir skólarnir luku skólaárinu á stórri sýningu sem allir nemendur í báđum bekkjunum tóku pátt í. Mikil áhersla var lögð á að nemendur næðu sem bestum tökum á spuna og miðaði öll kennsla eftir áramót að pví að setja upp leikritið og máta nemendur í hlutverk. Í raun unnu báđir kennararnir sem leikstjórar á vorönninni í samvinnu við aðra kennara við skólann.

\section{Mikilvægi samstarfsins}

Samvinna milli list- og verkgreinakennaranna var áberandi í öðrum skólanum. Allir list- og verkgreinakennararnir komu að leiksýningunni með einum eða öðrum hætti. Detta samstarf var eitt af pví sem gerði leiklistarkennsluna í Fjallaskóla auðveldari fyrir leiklistarkennarann. Hann talaði um að eftir að kennararnir hefðu farið að starfa saman hefði hann orðið var við meiri virðingu gagnvart sér og leiklistinni. Í hinum skólanum var ekki eins mikið um samstarf. Dó tók leiklistarkennarinn pátt í að setja á svið Landnámið með bekkjarkennurum í 5. bekk. Рað samstarf tókst vel pó að einstaka kennari vissi oft ekki hvað fram fór í leiklistartíma né hvaða listfag kennarinn var að kenna: „Oft var ég kölluð tónmenntakennari pegar ég kom ekki nálægt peirri kennslu.“

Leiklistarkennsla er í eðli sínu mjög fjölbreytt par sem ekki er nóg að nemendur lesi sér til um fagið heldur eiga peir líka að fá að iðka fagið. Leiklistarkennarinn parf bæði að gefa svigrúm fyrir sköpun og vera leiðandi í sköpuninni. Niðurstöðurnar eru í samræmi við hugmyndafræði Anderson (2006) um starfspróun leiklistarkennarans par sem kennarinn parf stöðugt að próa aðferðir sínar og verkefni og leyfa nemendum að koma með hugmyndir. Баð var áberandi í kennsluháttum hjá báðum kennurunum að peir tóku mið af hæfniviðmiðunum í leiklist með pví að vera með fjölbreytta kennsluhætti sem reyndu á virkni, pjálfun og sköpun. 


\section{Frá sjónarhorni kennarans:}

Niðurstöður rannsóknarinnar út frá sjónarhorni kennarans svara annarri rannsóknarspurningunni, sem var: Hvernig er hoegt að skilja og l'́sa starfspróun leiklistarkennarans yfir eitt skólaár? Dað sem stendur upp úr er pörfin á að vera viðurkenndur sem fagmaður í starfinu og að tilheyra skólasamfélaginu.

\section{Viðurkenning sem fagmaður í faginu}

Рað breytti öllu fyrir annan kennarann pegar hann fékk viðurkenningu sem fagmaður í leiklist: „Degar ég fékk bara að kenna leiklist, pað finnst mér vera mikli viðurkenning á mínu starfi /.../ ég kenni bara leiklist og er með mína stofu og er mjög ánægður.“ Miklar breytingar áttu sér stað eftir að leiklist varð viðurkennt fag í skólanum, samvinna við aðra list- og verkgreinakennara jókst til muna og kennarar fóru að tala saman: ,... pá fórum við að ræða um pað hvað við gætum gert og úr varð að setja upp leikrit." Skólastofurnar eru flestar óhentugar fyrir leiklistarkennslu og stundum purfti annar kennarinn að deila stofunni sinni með öðru fólki sem kom utan frá, p.e. sem heimsótti skólann endrum og sinnum: „... rýmið sem mér var gefið var ekki upp á marga fiska og ég hafði ekki aðgang að skólastofunni alltaf og purfti pá að fara inn í aðrar skólastofur sem voru stútfullar af stólum og borðum“.

\section{Sjálfmynd leiklistarkennarans}

Kennararnir voru sammála um að peir yrðu að fá að koma að ákvörðunum sem sneru að starfi peirra, t.d. samvinnu og samstarfi, og að peir gætu haft áhrif á pað hvernig stundataflan er sett upp: „Баð sem hentar einni listgrein tímalega parf ekki endilega að henta annarri grein.“ „... pegar allir list- og verkgreinakennarar vinna sama að ákveðnu verkefni verður til einhver sköpunarkraftur og verkefnin eru tekin upp á annað plan“. Kennarar verði líka að fá að hafa áhrif á endurmenntun sína og hvað háskólarnir eru að bjóða upp á „... pað parf að vera hvatning til að endurmennta sig“.

\section{Að tilheyra skólasamfélaginu}

Skólasamfélagið er samfélag kennara, nemenda, foreldra og starfsfólks sem á í daglegum samskiptum hvert við annað. Fyrir nýjan kennara getur pað skipt sköpum að tilheyra skólasamfélaginu. Alex Honneth (1995) heldur pví fram að hver einstaklingur purfi prenns konar viðurkenningu, p.e. frá: fjölskyldu, viðurkenningu réttarins og viðurkenningu í kringum hina svokölluðu samfélagshyggju. Ef engin samskipti eiga sér stað er hætta á að kennarinn einangrist. Báđir kennararnir í rannsókninni töluðu um mikilvægi samstarfsins við aðra kennara.

Nýútskrifaðir kennarar eiga oft erfitt með að fóta sig á nýjum vettvangi. Deir vita pá ekki hvað peir mega og eiga að gera í kennslu og eiga oftar en ekki í innri baráttu við sjálfa sig vegna pess að peir ná illa tökum á pví sem peir eru að gera: „Ég hafði tilhneigingu til að leyfa nemendum að taka yfir. Mér fannst oft erfitt að finna ákveðinn ramma utan um kennsluna, að skipuleggja kennsluna.“ Að koma inn í kennslu og hafa engan stuðning getur leitt til pess að kennarinn hreinlega brenni út og hætti í starfi. Detta óöryggi kennaranna getur orðið til pess að kennslan verði oft á tíðum ómarkviss og tilviljunarkennd.

\section{Frá sjónarhorni nemendanna:}

Niðurstöðurrannsóknarinnarútfrásjónarhorninemendannasvarapriðju rannsóknarspurningunni, sem var: Hver er upplifun og reynsla nemendanna af leiklistarkennslunni og pátttöku í sýningu? Dað sem stendur upp úr er að samkvæmt nemendum er skemmtilegt í leiklist. Deir tala um að leiklistarkennarar séu mikilvægir og að í gegnum leiklist læri peir að vinna með öðrum, líka pótt peir vilji pað ekki. 


\section{Að hlusta og taka tillit til annarra}

Í upphafi annar hafa nemendur gert sér ákveðnar hugmyndir um pað hvað leiklistarkennsla gengur út á. Aðeins örfáir nemendur gátu lýst pví hvað leikrænt ferli er og aðrir töluðu um leiki:

Ég held að leikrænt ferli sé að pú gerir eitthvað með bekkjarfélögunum pínum. Dú verður að bera virðingu fyrir pví sem aðrir eru að gera. Dú mátt ekki tala pegar aðrir eru að sýna og mátt ekki segja eitthvað ljótt um pað sem einhver annar er að gera. Leiklist gengur út á pað að hjálpa okkur að hætta að vera feimin og við lærum að setja okkur í spor annarra. (stúlka í Fjallaskóla)

Dessi stúlka var búin að læra að taka tillit til annarra bekkjarfélaga og að í leiklist vinni maður með öðrum. Strákarnir í Brekkuskóla voru sammála. Рað er hægt að læra að vera ekki feiminn:

Okkur finnst kennarinn okkar frábær, við lærum að vera ekki feimin og að pað er í lagi ef einhver horfir á pig. (strákar í Brekkuskóla)

Einn af strákunum í Fjallaskóla sagðist eiga auðvelt með að setja sig í spor annarra í leikræna ferlinu og að vinna með öðrum:

Í leiklist pá parf maður að snúa að áhorfendum og maður parf að tala hátt, og pú parft líka að vinna með öllum, pó svo að maður vilji pað ekki. Eins læri ég að nota leikmuni og búninga. (strákur í Fjallaskóla)

Stelpur í báðum skólunum töluðu um leiklist sem uppáhaldsfagið sitt par sem pær læra að hlusta og taka tillit:

Í leiklistartíma pá purfum við að hlusta á hvert annað og taka tillit til hvers annars, við lærum að segja pað sem við meinum og í dag pá pori ég að standa upp og tala. Ég er ekki lengur feimin. (stelpur í Fjalla- og Brekkuskóla)

\section{Að hafa gaman, leika og læra}

Í hópviðtali við stráka í Fjallaskóla kom fram að pað er gaman að leika og læra:

Við lærum að leika alls konar. Við lærum hvað leikrit eru, við getum fylgst með sögupræðinum og svo kunnum við að leika. Okkur finnst að leiklist ætti að vera prisvar sinnum í viku. (strákar í Fjallaskóla)

Strákarnir töluðu líka um mikilvægi hlutverkaleiksins:

Í leiklist pá getur maður verið hver sem er; ef pú vilt vera konungur eða fótboltamaður pá getur pú pað. (strákar í Fjallaskóla)

Leiklist reynir líka á samskiptahæfni nemenda og tala peir um að í gegnum leiklist purfi allur bekkurinn að vinna saman og að peir purfi að geta túlkað leikpersónur á sviði í samspili við meðleikara og notfært sér leikmuni, búninga og einfaldan sviðsbúnað. „Leiklistin hjálpar manni að vera ekki feiminn og pú verður að hlusta á hina krakkana“ (stúlka í Fjallaskóla). Önnur stúlka talaði um að „í gegnum leiklist pá lærum við samskipti og samvinnu“ (stúlka í Brekkuskóla). Sumir nemendur sáu tækifæri í pví að læra að leika hlutverk, læra að leika sér og búa til sögur. Einn strákur í Fjallaskóla sagði að sér fyndist leiklist skemmtileg vegna pess: „að í leiklist pá leikum við okkur og gerum skemmtilega leiki og aðaláherslan er að læra og hafa gaman“. 
Í töflu 2 hefur verið tekin saman upplifun nemenda af námi í leiklist að hausti og vori og hún tengd við hæfniviðmið í leiklist, samkvæmt aðalnámskrá grunnskóla.

Tafla 2. Upplifun af námi í leiklist.

\begin{tabular}{|c|c|c|}
\hline \multirow[t]{2}{*}{ Upplifun af námi í leiklist } & \multicolumn{2}{|c|}{ Dættir sem hafa áhrif á nám í leiklist } \\
\hline & Haust & Vor \\
\hline \multirow{3}{*}{$\begin{array}{l}\text { Í tengslum við } \\
\text { sviðsetningu og } \\
\text { leiksýningu }\end{array}$} & Geta sagt frá ferlinu við & Til að hafa gaman og læra \\
\hline & uppsetnıngu leiksynıngar & Geta túlkað leikpersónu á sviði í \\
\hline & $\begin{array}{l}\text { Farið í spuna, leiki og sagðar } \\
\text { sögur }\end{array}$ & góðu samspili við meðleikara \\
\hline \multirow[t]{4}{*}{$\begin{array}{l}\text { Í tengslum við } \\
\text { hæfniviðmið }\end{array}$} & $\begin{array}{l}\text { Að læra að setja sig í spor } \\
\text { annarra }\end{array}$ & $\begin{array}{l}\text { Geta notfært sér leikmuni, } \\
\text { búninga og einfaldan sviðsbúnað }\end{array}$ \\
\hline & $\begin{array}{l}\text { Að læra að tjá sig og sýna } \\
\text { virðingu }\end{array}$ & $\begin{array}{l}\text { Læra að vinna með öðrum án } \\
\text { pess endilega að vilja pað }\end{array}$ \\
\hline & & Læra að hlusta og taka tillit \\
\hline & & $\begin{array}{l}\text { Geta beitt og tekið á móti } \\
\text { uppbyggilegri gagnrýni }\end{array}$ \\
\hline
\end{tabular}

Dað er sýnilegur munur á upplifun nemenda á leiklistarnáminu frá hausti til vors. Sá páttur sem hefur mest áhrif er að í báđum skólunum voru settar upp sýningar á vorönninni. Kennslan tók mið af pví á vorönninni og unnu kennarar pá eins og leikstjórar. Mikil áhersla var á spuna og hópastarf ásamt leiktúlkun og persónusköpun.

\section{Ánægjuleg upplifun í leiklist}

Degar kemur að ánægjulegri upplifun nemenda í leiklist kemur skýrt fram hvað nemendum finnst gaman að læra í gegnum leiklist og nefna peir að engar tvær kennslustundir séu eins. Í töflu 3 eru niðurstöður um ánægjulega upplifun nemenda í leiklist:

Tafla 3. Ánægjuleg upplifun í leiklist

\begin{tabular}{l}
\hline Ánægjuleg upplifun \\
\hline Leiklist er skemmtileg \\
Hafa áhrif á hvað er kennt og purfa ekki að sitja allan tímann \\
Líður vel í tímum og treysta kennaranum \\
Læra að vera ekki feimin og pað er í lagi ef einhver horfir á mann \\
\hline
\end{tabular}

Dað kemur skýrt fram í viðtölunum við nemendur að peir geti stundum ráðið pví hvað er kennt; peir hafi áhrif á kennsluna.

Í hópviðtali við drengi í Fjallaskóla var petta greinilegt: „Í leiklist getur maður verið maður sjálfur og pú parft ekki að sitja allan tímann og pú hefur áhrif á hvað er kennt.“

Einnig tala hóparnir um hvað kennarinn sé mikilvægur:

Dað geta ekki allir kennt leiklist; til að geta kennt leiklist pá parf persónan að vera skapandi, ekki feimin, og kennarinn parf að vera leikari par sem kennarinn setur upp sýningar með peim (nemendunum). (hópviðtal í Fjallaskóla) 
Ánægjuleg upplifun nemenda í leiklist sem birtist í viðtölunum bendir öll í eina átt; að í leiklist er gaman og að peir kunna að meta leiklistina. O’Toole talar um að pegar leiklist sé kennd sem listgrein pá fái nemendur æfingu í að leika og koma fram, peir pjálfist í hlutverkaleik, að geta beitt mismunandi aðferðum við sviðssetningu, spuna, túlkað persónur, notað leikmuni og beitt rýmis-, radd- og líkamsvitund á meðvitaðan hátt (O’Toole, 2015, bls. 186). Upplifun nemenda af námi í leiklist er einnig í takt við hugmyndir O'Toole um leiklistarkennslu og hún endurspeglar ánægju beirra en ekki síður læsi á leiklist í víðu samhengi og hvernig leiklistin dýpkar skilning nemenda á sjálfum sér, mannlegu eðli og samfélagi (O’Toole, 2015).

\section{Frá sjónarhorni skólastjóranna:}

Niðurstöđurrannsóknarinnarútfrásjónarhorniskólastjórannasvarafjórðurannsóknarspurningunni, sem var: Hvernig skilgreina skólastjórarnir í bádum skólunum menningu leiklistar? Dað sem stendur upp úr er að skólastjórarnir í báðum skólunum leggja áherslu á mikilvægi leiksýninga og að námið sé skemmtilegt. Eins tala peir um leiklistina sem vörumerki fyrir skólana sína. Í báđum skólunum er rík hefð list- og verkgreina. Hugmyndafræði skólastjóra Brekkuskóla er að nám eigi að vera skemmtilegt.

Skólastjórinn leggur ríka áherslu á sampættingu við list- og verkgreinar.

Sem skólastjóri legg ég línurnar og mínar línur eru á list- og verkgreinar. Ég vil að kennarar vinni saman og legg áherslu á samtal og kennslufræði. (skólastjóri Brekkuskóla)

Í Fjallaskóla er hugmyndafræði skólastjórans byggð á frumkvæði og samvinnu.

Ég hef mikinn metnað fyrir skólanum mínum og ég legg áherslu á að kennarar hafi pað líka. Skólinn er stór og ég treysti kennurunum mínum til að vera faglegir leiðtogar. (skólastjóri Fjallaskóla)

Leiklist hefur verið á stundatöflu Fjallaskóla í mörg ár. Meðal pess sem leiklistin hefur gert fyrir skólann er að tengja saman heimili og skóla:

Ég sá margt breytast pegar við settum leiklist inn í stundatöfluna. Nemendur sem áttu í vandræðum í náminu eða voru lagðir í einelti taka fullan pátt í leiklistinni. Allir koma að sýningunni í 6. bekk og nemendur eru spenntir að taka pátt. Leiklistin hefur hjálpað öllu skólasamfélaginu. (skólastjóri Fjallaskóla)

Samkvæmt skólastjóra Brekkuskóla er menningarlegt uppeldi í gegnum list- og verkgreinar hluti af skólastarfinu.

Ef nemendur kynnast ekki listum heima hjá sér er pað hlutverk skólans að kynna listir fyrir peim. Ef skólinn getur ekki boðið upp á leiklist eða dans verða nágrannaskólar að vinna saman að pví að tryggja að svo sé. (skólastjóri Brekkuskóla)

Раð sem er líkt með báðum skólunum er áhersla á list- og verkgreinar. Báðir skólarnir höfðu menntaða leiklistarkennara sem kenndu fagið. Í Brekkuskóla hafa bekkjarkennarar kennt leiklist ef ekki fæst menntaður leiklistarkennari til starfa. Í Fjallaskóla er góð aðstaða fyrir bæði list- og verkgreinarnar. Skólastjórinn leggur áherslu á samvinnu og eru list- og verkgreinarnar með góða aðstöðu á sér gangi í skólanum.

par sem skólinn er mjög stór er auðveldara fyrir okkur að bjóða upp á leiklist fyrir heilan bekk eins og gert er í tónmennt og danskennslu. Ef bekkjunum yrði skipt í tvennt pá hefði skólinn ekki efni á pví að vera með leiklist. Aðrir kennarar virða pað sem leiklistarkennarinn er að gera. Deir hafa áttað sig á pví að peirra starf verður auðveldara t.d. pegar setja á upp sýningu eða bjóða á bekkjarkvöld. Bæði leik- og tónmenntakennararnir hafa aðstöðu og tíma til að sinna sínu starfi. (skólastjóri Fjallaskóla) 
Leiklist hefur verið á stundatöflu beggja skóla um hríð. Nemendur í Fjallaskóla fá leiklist í 5., 6. og 7. bekk en í vinnusmiðjum á yngra stiginu.

Dað breyttist allt eftir að við settum leiklist inn á stundatöflu. Nemendum líkar vel við fjölbreytnina og fá að setja upp stuttar sýningar í hverri viku og síðan að taka pátt 1 stóru sýningunni okkar í 6. bekk sem er orðin fastur liður í skólastarfinu. (skólastjóri Fjallaskóla).

Kostir við pað að hafa leiklist eru margir að sögn skólastjóranna. Nemendur í Fjallaskóla eru meira skapandi eftir að leiklistin varð fastur liður í stundatöflu og peir eru hamingjusamari nemendur, að sögn skólastjórans. Hann segist ekki hafa gert neina vísindalega könnun en vill meina að pað аð hafa bæett leiklist inn á stundatöflu sé pað besta sem hann hafi gert fyrir skólann og skólabraginn. Deir nemendur sem hafi átt erfitt í skólanum fái hvatningu og por til að vera hluti af hópnum í gegnum leiklist.

Баð að kenna leiklist og að bjóða upp á sýningar má túlka sem vörumerki skólanna. Skólastjórarnir báđir eru stoltir af peim sýningum sem skólarnir bjóđa upp á og tala báðir um hvað skólasamfélagið breyttist eftir að leiklistin varð páttur í almennu skólastarfi.

\section{Samantekt og umræða}

Ísland er í fararbroddi pegar kemur að listgreinum í grunnskóla. Ekkert annað land í Evrópu hefur leiklist sem listgrein í aðalnámskrá og aðrar pjóðir horfa til Íslands með hvernig til tekst við innleiðingu leiklistar sem kennslugreinar. Dví tel ég að pað purfi sérstaklega að hlúa að faginu. Niðurstöður rannsóknarinnar um margbrotið starf leiklistarkennarans eru í samræmi við hugmyndafræði Anderson (2006) um starfspróun leiklistarkennarans. Hann heldur bví fram að kennarinn purfi stöðugt að próa aðferðir sínar og verkefni og leyfa nemendum að koma með hugmyndir. Баð að hlustað sé á nemendur kemur fram í ánægjulegri upplifun peirra í leiklist og er í takt við hugmyndir O’Toole um leiklistarkennslu en ánægjan endurspeglar ekki síður læsi á leiklist í víðu samhengi (O’Toole, 2015). Nám í leiklist getur hjálpað nemendum að skilja sögu, menningu og samfélag í heild um leið og pað hjálpar peim að proskast sem persónur (Thorkelsdóttir, 2016) og taka pátt í eigin menningarsamfélagi (Fleming, 2012). Kemmis og félagar (2014) halda pví fram að til að breyta starfsháttum sé ekki nóg að breyta pví hvernig kennarar kenna eða nemendur læra, heldur verði að breyta öllum starfsháttum innan skólans par sem petta sé allt samtengt. Hugmyndafræðin að baki uppbyggingu starfshátta gerir ráð fyrir pví að pegar leiklistarkennari gengur inn í skólasamfélagið sé starfsvettvangurinn fyrir hendi. Dessi vettvangur hefur pegar byggt upp sinn eigin stíl starfshátta í tengslum við yrðingar, gerðir og tengsl. Hér er einnig alltaf um pað аð ræða að breyta uppbyggingu starfshátta á tilteknum vettvangi. Фví er pað svo að pegar gerðar eru breytingar á sviði menntunar, t.d. með pví að bæta nýrri námsgrein inn í námskrána, pá nægir ekki að hliðra einfaldlega til kennsluaðferðum eða námstilhögun nemenda; pað verður að líka horfa til allra pátta starfseminnar. Skólastjórinn hefur nokkuð frjálsar hendur með pað hvort leiklist sé kennd eða ekki. Ef skólastjórinn er hlynntur leiklistarkennslu býr hann til rými fyrir leiklistina. Oft er pað pó á kostnað annarra listgreina, sem er miður. O’Toole og O’Mara (2007) telja að pað ríki ákveðinn kvíði hjá skólastjórnendum varðandi leiklistarkennslu. Leiklistin er gjarnan færð inn í námskrár en jafnharðan tekin út aftur. Detta veldur óöryggi hjá skólastjórnendum og peir vita hreinlega ekki hvað peir eiga að gera við leiklist sem námsgrein. Deir skilja og viðurkenna mikilvægi hennar en eru ef til vill tregir til að fylgja pví frekar eftir, prátt fyrir fjölmarga kosti leiklistarkennslu. Kveðið er á um раð í aðalnámskránni að listgreinar og verkgreinar skuli hafa jafnt vægi innan heildartímans sem gefinn er upp í viðmiðunarstundaskrá. Рað er ljóst að nemendur eru ánægðir með að fá leiklistarkennslu og vel var hlúð að peim kennurum sem tóku pátt í rannsókninni. Pó parf meira til. Að mínu mati parf að efla ráðgjöf, stuðning og starfspróun leiklistarkennarans ásamt pví að efla einnig stuðningsnet og leiðsögn fyrir nýja kennara. Rannsóknir sýna að nýútskrifaðir kennarar geta átt erfitt með að fóta sig í nýrri grein. Peir vita oft ekki hvað peir mega og eiga 
að gera í kennslu og eiga oftar en ekki í innri baráttu við sjálfa sig af pví að peir ná ekki tökum á pví sem peir eru að gera. Að koma inn í kennslu og hafa engan stuðning getur leitt til pess að kennarinn hreinlega brenni út og hætti í starfi. Petta óöryggi verður til pess að kennslan getur orðið tilviljunarkennd og pað virðist sem kennarar eigi erfitt með að skipuleggja kennsluna og byggja ofan á hana. Pá tel ég að pað væri til bóta ef leiklistin fengi sína eigin skólastofu. Kynna pyrfti möguleika greinarinnar til framtíðar í öllum skólum landsins enda sampættir hún ekki bara allar listgreinarnar heldur skapar tækifæri til virkrar pátttöku nemenda, lýðræðislegrar ákvarðanatöku, samskipta og samvinnu.

\section{Complexity of drama teaching and drama teachers' role in relation to its implementation?}

The objective of this article is to shed light on the complexity of drama teaching and drama teachers' role in relation to the implementation of drama in compulsory education in Iceland. The article is based on my PhD study, entitled Understanding Drama Teaching in Compulsory Education in Iceland: A Micro-ethnographic Study of the Practice of Two Drama Teachers. The research project was motivated by the fact that in 2013 drama was added as a compulsory subject for all students in primary and lower secondary curricula in Iceland. To include a new subject raises many fresh questions regarding how drama can contribute to students' learning within the arts. Why is this art subject obligatory? What can be learned by taking drama? Who has the competence to teach this subject, and - if it is used as a framework to support learning in other subjects - who can elaborate on such a framework in a way that best brings out its potential as an art subject? When a new national curriculum guide for drama is created, is there a need for continuous education to meet the changes introduced? How can teachers, who may not be used to including drama as a working mode, become qualified to teach drama? What kind of support is needed from the education system in order to make this work? What could be the contribution of this arts subject that may not be easily accomplished in other subjects? Those questions are examples of myriads of questions that must be asked when a new subject is made obligatory at the same time as fundamental changes are presented in the national curriculum. The study aims to answer the questions, which relate to the question of drama as an arts subject. This research sets out to discover how drama is implemented in compulsory education, and how teaching is practiced in two Icelandic schools. The overarching research question is: How is drama, as a subject, implemented in Icelandic compulsory education? An ethnographic study of the culture and the context for the implementation of drama was carried out within a socio-cultural framework of understanding. The ethnographic account is based on thick descriptions and thematic narrative analyses summed up as a cultural portrait of the drama teaching practices in Hillcrest (grade 5) and Mountain-line (grade 6) schools, respectively. The theory of practice architectures by Stephen Kemmis and Peter Grootenboer is used to interpret the findings. In this practice theory, practice is defined as a nexus of sayings, doings and relatings, dependent on arrangements in the practice architectures. Enabling and constraining arrangements in the practice architectures connected to the implementation of drama as a subject in compulsory education are identified and discussed. The study calls for changes in opportunities for the professional development of drama teachers. Further, it calls for a reconceptualization of how a drama teacher's learning trajectory could be designed in order to support the drama teacher and his or her resilience and motivation to transform the teaching for the benefit of the students and their learning process.

Keywords: Drama, arts education, curriculum, practice architecture 


\section{Um höfundinn}

Rannveig Björk Porkelsdóttir (rbth@hi.is) er aðjúnkt við Menntavísindasvið Háskóla Íslands. Hún lauk B.Ed.-prófi frá Háskóla Íslands árið 2003 og MA.-prófi í uppeldis- og menntunarfræðum frá sama skóla árið 2009 og MA.-prófi í hagnýtri menningarmiðlun frá sagfræði- og heimspekideild árið 2012. Hún lauk doktorsprófi frá Kennaradeild Norska tækni- og vísindaháskólans, (NTNU) í Prándheimi 2016 par sem hún skrifaði um innleiðingu leiklistar í grunnskóla á Íslandi. Rannsóknarsvið hennar tengist meðal annars listkennslu og leiklist.

\section{About the author}

Rannveig Björk Thorkelsdóttir (rbth@hi.is) is adjunct lecturer at the University of Iceland, School of Education. She finished her B.Ed. degree from University of Iceland in 2003, M.A. degree in Educational theory 2009 and M.A. degree in applied studies in Culture and Communication from Faculty of History and Philosophy 2012. She holds a Ph.D. from Norwegian University of Science and Technology (NTNU) with emphasis on drama and theatre study. In her research and practice she focuses on drama and artistic approaches to teaching and learning.

\section{Heimildir}

Abbs, P. (2003). Against the flow: Education, the arts and postmodern culture. London: Routledge.

Anderson, M. (2006). What is a drama teacher? Some stories from praxis. Í L.A. McCammon og D. McLauchlan (ritstjórar), Universal mosaic of drama and theatre. The IDEA 2004 dialogues (bls. 99-108). Ottawa: IDEA.

Anderson, M. (2012). Master class in drama education. Transforming teaching and learning. London: Continuum.

Ása Ragnarsdóttir og Rannveig Porkelsdóttir. (2010). Skapandi nám í gegnum leiklist. Netla - Veftímarit um uppeldi og menntun. Sótt af http://netla.hi.is/menntakvika2010/006.pdf

Bamford,A. (2011). Arts and cultural education in Iceland. Reykjavík: Ministry of Education, Science and Culture.

Fleming, M. (2012). The arts in education. An introduction to aesthetics, theory and pedagogy. London: David Fulton.

Honneth, A. (1995). The struggle for recognition: The moral grammar of social conflicts. Cambridge: Polity Press.

Kemmis, S. og Grootenboer, P. (2008). Situating praxis in practice. Í S. Kemmis, T. Smith og J. Smith (ritstjórar), Enabling praxis: Challenges for education (bls. 37-62). Rotterdam: Sense.

Kemmis, S., Wilkinson, J., Edwards-Groves, C., Hardy, I., Grootenboer, P. og Bristol, L. (2014). Changing practices, changing education. Dordrecht: Springer.

Keuchel, S. (2016). Different definitions and focus on arts education. An explorative international empirical study. Í A. Sæbø (ritstjóri), INRAE yearbook 2016. At the crossroads of arts and culture education. Queries meet assumptions (bls. 31-40). Münster:Waxmann.

Landlæknisembættið. (2004). Offita barna og unglinga. Forvarnir og meðferð. Sótt af https://www.landlaeknir. is/servlet/file/store93/item2421/2159.pdf

Mennta- og menningarmálaráðuneytið. (2013). Aðalnámskrá grunnskóla 2011:Almennur hluti: Greinasvið 2013. [Önnur útgáfa með breytingum]. Reykjavík: Höfundur.

Meyers, M. D. (1997). Qualitative research in information systems. MIS Quarterly, 21(2), 241-242.

O'Toole, J. (2015). When advocacy meets opportunity... what's the reality? Establishing drama in the curriculum. Í M. Fleming, L. Bresler og J. O’Toole (ritstjórar), The Routledge international handbook of the arts and education, (bls. 185-193). London: Routledge.

O'Toole, J. og O'Mara, J. (2007). Proteus, the Giant at the Door: Drama and theatre in the curriculum. I L. Bresker (ritstjóri), International handbook of research in arts education (bls. 203-218). Dordrecht: Springer.

Rannveig Björk Dorkelsdóttir. (2012). Leikið með listina. Reykjavík: Háskólaprent.

Schatzki, T. R. (1996). Social practices: A Wittgensteinian approach to human activity and the social. New York: Cambridge University Press.

Schatzki, T. R. (2002). Introduction: Practice theory. Í T. R. Schatzki, K. Knorr-Cetina og E. von Savigny (ritstjórar), The practice turn in contemporary social theory (bls. 10-21). London: Routledge. 
Schonman, S. (2016). Making sense of arts education wrestling with two critical myths in the field. I A. Sæbø (ritstjóri), INRAE yearbook 2016. At the crossroads of arts and culture education. Queries meet assumptions (bls. 21-30). Münster:Waxmann.

Ragnarsdóttir, Á. H. og Thorkelsdóttir, R. B. (2013). Can drama, through Icelandic tales, increase children's vocabulary? Í R. B. Thorkelsdóttir og Á. H. Ragnarsdóttir (ritstjórar), Earth-Air-Water-Fire, (bls. 13-35). Reykjavík: Háskólaprent.

Thorkelsdóttir, R. B. (2016). Understanding drama teaching in compulsory education in Iceland: A micro-ethnographic study of the practice of two drama teachers. Trondheim: Norwegian University of Science and Technology.

Winner, E., Goldstein, T., \& Vincent-Lancrin, S. (2013), Art for art's sake? The impact of arts education, educational research and innovation. OECD publishing. doi:10.1787/9789264180789-en

Østern,A.-L., Toivanen,T, ogViirret,T.L. (2016). Drama boreale - Perspectives on drama education in Finland and Norway - Struggling for a place in the educational system. Í E. Kimonen (ritstjóri), Reforming school education: readings and activities for educational studies. Rotterdam: Sense.

Rannveig Björk Porkelsdóttir. (2018).

Margbrotið hlutverk leiklistarkennarans í kennslu leiklistar í tengslum við innleiðingu á leiklist.

Netla - veftímarit um uppeldi og menntun. Sérrit 2018 - Bókmenntir, listir og grunnpættir menntunar.

Menntavísindasvið Háskóla Íslands.

Sótt af http://netla.hi.is/serrit/2018/bokmenntir_listir_menntun/07.pdf

https://doi.org/10.24270/serritnetla.2019.20 